\title{
OCENA WIEDZY PACJENTEK ODDZIAŁU CHIRURGICZNEGO NA TEMAT ZASAD SAMOOPIEKI PO ZABIEGU MASTEKTOMII
}

\section{KNOWLEDGE OF POST MASTECTOMY SELF-CARE PRINCIPLES AMONG FEMALE PATIENTS OF THE SURGICAL DEPARTMENT}

\author{
Anna Kapusta ${ }^{1}$, Anna Kaczyńska1, Mariusz Panczyk², Jarosława Belowska², \\ Aleksander Zarzeka², Joanna Gotlib² \\ ${ }^{1}$ studentka pielęgniarstwa \\ Warszawski Uniwersytet Medyczny \\ ${ }^{2}$ Zakład Dydaktyki i Efektów Kształcenia \\ Warszawski Uniwersytet Medyczny
}

DOI: http://dx.doi.org/10.20883/pielpol.2016.8

\section{STRESZCZENIE}

Wstęp. W Polsce rak piersi jest najczęściej występującym nowotworem złośliwym u kobiet. Z każdym rokiem liczba nowych zachorowań wzrasta. Na podstawie ostatniego opublikowanego raportu danych Centrum Onkologii - Instytutu im. Marii Skłodowskiej-Curie w Warszawie z 2009 r. na raka sutka w 2009 r. zachorowały 15752 kobiety, a 5242 zmarty.

Cel. Cel pracy stanowiła próba oceny wiedzy pacjentek oddziału chirurgicznego na temat zasad samoopieki po zabiegu mastektomii.

Materiał i metody. Badaniami objęto 100 kolejnych, wyrażających zgodę na badania ankietowe pacjentek oddziału chirurgicznego Wojewódzkiego Szpitala Specjalistycznego w Radomiu, przebywających w oddziale po zabiegu mastektomii. Taki dobór pacjentek do badania spełnia warunki doboru losowego. W badaniu zastosowano metodę sondażu diagnostycznego; wykorzystano technikę ankietową.

Wyniki. W badanej grupie kobiet $73 \%$ najczęściej pozyskuje informacje dotyczące profilaktyki raka piersi z telewizji, radia oraz gazet. Dla $75 \%$ respondentek czynnik genetyczny odgrywa największą rolę w zwiększeniu ryzyka zachorowania na raka piersi. Według $83 \%$ badanych skutecznym środkiem walki z rakiem jest odpowiednio dobrane leczenie. Samobadanie piersi potrafi przeprowadzić $77 \%$ respondentek. Zdaniem $87 \%$ respondentek najrzetelniejszym źródłem wiedzy na temat samoopieki po zabiegu mastektomii jest lekarz.

Wnioski. 1. Uzyskane wyniki badań świadczą o niedostatecznej wiedzy pacjentek oddziału chirurgicznego na temat zasad samoopieki po zabiegu mastektomii. 2. Poziom wiedzy respondentek na temat profilaktyki raka piersi w znaczny sposób wpływa na podejmowane przez nie działania prewencyjne. 3. Wyniki badań własnych potwierdzają tezę, że brak ogólnodostępnych publikacji i szeroko zakrojonej edukacji na temat profilaktyki raka piersi, a zwłaszcza samoopieki po zabiegu mastektomii ma wpływ na poziom wiedzy kobiet. 4. Według badanej grupy kobiet lekarze i pielęgniarki są najodpowiedniejszymi osobami do zapoznawania z zasadami samoopieki po zabiegu mastektomii, ale są oni za mało zaangażowani w szerzenie wiedzy na ten temat.

SŁOWA KLUCZOWE: wiedza, pacjenci.

\section{ABSTRACT}

Introduction. Breast cancer is the most frequently experienced malignant neoplasm among women in Poland. The number of new breast cancer cases increases every year. According to the latest report (2009) by the Oncology Centre - Maria Skłodowska-Curie Institute in Warsaw, in 2009 as many as 15752 women developed breast cancer and 5242 of them died.

Aim. An attempt to assess the knowledge of female patients hospitalized in the surgical department about the principles of post mastectomy self-care.

Material and methods. The study involved 100 consecutive female patients of the Surgical Department of the Regional Specialist Hospital in Radom who underwent a mastectomy there and gave their consent to participate in the survey. This kind of patient selection for the study meets the requirements of a random selection. A diagnostic survey by means of questionnaires was used in the study.

Results. $73 \%$ of the study participants most often got information on breast cancer prophylaxis from television, radio, and press. For $75 \%$ of the respondents the genetic factor was most likely to increase the risk of breast cancer. As many as $83 \%$ of the study participants believed that proper treatment was an effective weapon against cancer. $77 \%$ of the total were able to perform a breast selfexamination. $87 \%$ of the respondents said that a doctor was the most reliable source of knowledge of post mastectomy self-care.

Conclusions. 1. The study results demonstrated that female patients of the surgical department had insufficient knowledge of the principles of post mastectomy self-care. 2 . The level of knowledge of the study participants about breast cancer prophylaxis significantly influenced prevention actions they undertook. 3. Our study results confirmed the thesis that the lack of publicly available publications and a broad-based education campaign on breast cancer prophylaxis and post mastectomy self-care in particular have a great influence on the level of women's knowledge. 4. According to the study group, doctors and nurses were the most appropriate persons that could provide information on the principles of post mastectomy self-care, but they were not enough engaged in sharing this knowledge.

KEYWORDS: knowledge, patients. 


\begin{tabular}{|c|c|c|c|}
\hline \multirow{5}{*}{2.} & \multirow{5}{*}{$\begin{array}{l}\text { Czy według Pani można } \\
\text { zapobiec chorobie nowo- } \\
\text { tworowej?/In your opinion, } \\
\text { can cancer be prevented? }\end{array}$} & $\begin{array}{l}\text { Zdecydowanie tak/ } \\
\text { Strongly yes }\end{array}$ & 19 \\
\hline & & $\begin{array}{l}\text { Raczej tak/ } \\
\text { Rather yes }\end{array}$ & 45 \\
\hline & & $\begin{array}{l}\text { Nie mam zdania/ } \\
\text { No opinion }\end{array}$ & 2 \\
\hline & & $\begin{array}{l}\text { Raczej nie/ } \\
\text { Rather no }\end{array}$ & 21 \\
\hline & & $\begin{array}{l}\text { Zdecydowanie nie/ } \\
\text { Strongly no }\end{array}$ & 13 \\
\hline \multirow{6}{*}{3.} & \multirow{6}{*}{$\begin{array}{l}\text { Jak często chodzi Pani } \\
\text { na kontrolę do lekarza ze } \\
\text { względu na ryzyko zacho- } \\
\text { rowania na raka piersi?/ } \\
\text { How often do you go for } \\
\text { a check-up with your } \\
\text { doctor due to the risk of } \\
\text { developing breast cancer? }\end{array}$} & Raz na pół roku/ & \\
\hline & & Once during each & 7 \\
\hline & & Raz na rok/ & 39 \\
\hline & & Once a year & \\
\hline & & Rzadziej/Less often & 11 \\
\hline & & $\begin{array}{l}\text { Nie chodzę w ogóle/ } \\
\text { I do not go at all }\end{array}$ & 43 \\
\hline
\end{tabular}

Źródło: opracowanie własne

Source: author's own analysis

Tabela 3. Poziom wiedzy pacjentek oddziału chirurgicznego Wojewódzkiego Szpitala Specjalistycznego w Radomiu na temat raka piersi Table 3. Level of knowledge of female patients hospitalized in the surgical department of the Regional Specialist Hospital in Radom about breast cancer

\begin{tabular}{|c|c|c|c|}
\hline $\begin{array}{l}\text { Lp./ } \\
\text { Item } \\
\text { no. }\end{array}$ & Pytania/Questions & Odpowiedzi/Answers & $\begin{array}{l}\text { Liczba od- } \\
\text { powiedzi/ } \\
\text { Number of } \\
\text { answers }\end{array}$ \\
\hline \multirow{13}{*}{1.} & \multirow{13}{*}{$\begin{array}{c}\text { Proszę zaznaczyć } \\
\text { czynniki zwiększają- } \\
\text { ce ryzyko zachoro- } \\
\text { wania na raka piersi } \\
\text { (można zaznaczyć } \\
\text { kilka odpowiedzi)/ } \\
\text { Please tick from the } \\
\text { list below factors } \\
\text { increasing the risk } \\
\text { of developing breast } \\
\text { cancer (more than } \\
\text { one answer can be } \\
\text { chosen) }\end{array}$} & Wiek/Age & 73 \\
\hline & & Płeć/Gender & 68 \\
\hline & & $\begin{array}{l}\text { Czynnik genetyczny/ } \\
\text { Genetic factor }\end{array}$ & 75 \\
\hline & & $\begin{array}{l}\text { Antykoncepcja/ } \\
\text { Contraception }\end{array}$ & 23 \\
\hline & & $\begin{array}{c}\text { Wczesna pierwsza } \\
\text { miesiączka/ } \\
\text { Early age of menarche }\end{array}$ & 29 \\
\hline & & $\begin{array}{l}\text { Późna menopauza/ } \\
\text { Late menopause }\end{array}$ & 18 \\
\hline & & $\begin{array}{l}\text { Niezdrowy tryb życia (zła } \\
\text { dieta, brak aktywności } \\
\text { fizycznej, stosowanie }\end{array}$ & \\
\hline & & $\begin{array}{l}\text { używek)/Unhealthy } \\
\text { lifestyle (poor diet, lack } \\
\text { of physical activity, } \\
\text { stimulant use) }\end{array}$ & 47 \\
\hline & & Otyłość/Obesity & 20 \\
\hline & & $\begin{array}{l}\text { Późna pierwsza ciąża/ } \\
\text { Late first pregnancy }\end{array}$ & 33 \\
\hline & & $\begin{array}{c}\text { Noszenie ciasnych } \\
\text { biustonoszy/ } \\
\text { Wearing } \\
\text { a tight bra }\end{array}$ & 25 \\
\hline & & $\begin{array}{l}\text { Bezdzietnośćl } \\
\text { Childlessness }\end{array}$ & 17 \\
\hline & & $\begin{array}{l}\text { Wszystkie odpowiedzi/ } \\
\text { All ansewrs }\end{array}$ & 9 \\
\hline
\end{tabular}

\begin{tabular}{|c|c|c|c|}
\hline \multirow{8}{*}{2.} & \multirow{8}{*}{$\begin{array}{l}\text { Co według Pani } \\
\text { decyduje o skutecz- } \\
\text { nym wyleczeniu } \\
\text { raka piersi? } \\
\text { (można zaznaczyć } \\
\text { kilka odpowiedzi)/In } \\
\text { your opinion, what } \\
\text { determines suc- } \\
\text { cessful treatment of } \\
\text { breast cancer? } \\
\text { (more than one } \\
\text { answer can be } \\
\text { chosen) }\end{array}$} & $\begin{array}{l}\text { Odpowiednie leczenie/ } \\
\text { Proper treatment }\end{array}$ & 83 \\
\hline & & $\begin{array}{c}\text { Wczesne wykrycie } \\
\text { choroby/Early detection } \\
\text { of the disease }\end{array}$ & 71 \\
\hline & & $\begin{array}{l}\text { Wiek chorej osoby/ } \\
\text { Patient's age }\end{array}$ & 57 \\
\hline & & $\begin{array}{l}\text { Obecność bliskich osób/ } \\
\text { Support from close } \\
\text { relatives and friends }\end{array}$ & 18 \\
\hline & & Dieta/Diet & 22 \\
\hline & & $\begin{array}{c}\text { Aktywność fizyczna/ } \\
\text { Physical activity }\end{array}$ & 13 \\
\hline & & $\begin{array}{l}\text { Raka piersi nie da się } \\
\text { wyleczyć/Breast cancer } \\
\text { cannot be cured }\end{array}$ & 3 \\
\hline & & Inne/Others & - \\
\hline \multirow{8}{*}{3.} & \multirow{8}{*}{$\begin{array}{c}\text { Jakie objawy } \\
\text { według Pani są } \\
\text { najbardziej } \\
\text { charakterystyczne } \\
\text { dla raka piersi? } \\
\text { (można zaznaczyć } \\
\text { kilka odpowiedzi)/ } \\
\text { Which symptoms } \\
\text { and signs are the } \\
\text { most } \\
\text { characteristic of } \\
\text { breast cancer? } \\
\text { (more than one } \\
\text { answer can be } \\
\text { chosen) }\end{array}$} & Ból piersi/Breast pain & 15 \\
\hline & & $\begin{array}{l}\text { Krwisty wyciek z bro- } \\
\text { dawki sutkowej/Bloody } \\
\text { discharge from the } \\
\text { nipple }\end{array}$ & 27 \\
\hline & & $\begin{array}{l}\text { Powiększenie pacho- } \\
\text { wych węztów chłonnych/ } \\
\text { Enlargement of the }\end{array}$ & 39 \\
\hline & & axillary lymph nodes & \\
\hline & & $\begin{array}{l}\text { Obrzęki piersi/ } \\
\text { Breast swelling }\end{array}$ & 19 \\
\hline & & $\begin{array}{l}\text { Guzki na piersiach/ } \\
\text { Breast nodules }\end{array}$ & 45 \\
\hline & & $\begin{array}{l}\text { Owrzodzenie piersi/ } \\
\text { Ulceration of the breast }\end{array}$ & 15 \\
\hline & & $\begin{array}{l}\text { Zaczerwienienie piersi/ } \\
\text { Reddening of the breast }\end{array}$ & 27 \\
\hline
\end{tabular}

Źródło: opracowanie własne

Source: author's own analysis

Większość kobiet biorących udział w badaniu deklarowała, że potrafi przeprowadzić samobadanie piersi poprzez oglądanie, skontrolowanie piersi i węzłów chłonnych pachowych za pomocą dotyku. Niemniej jednak spośród badanej grupy 37 respondentek nie wykonuje takich badań w ogóle, pomimo że połowa z nich wie, iż działania te mogą przyczynić się do wczesnego wykrycia nowotworu piersi (Tabela 4).

Tabela 4. Ocena wiedzy pacjentek oddziału chirurgicznego Wojewódzkiego Szpitala Specjalistycznego w Radomiu na temat samobadania piersi

Table 4. Assessment of knowledge of female patients hospitalized in the surgical department of the Regional Specialist Hospital in Radom about breast self-examination

\begin{tabular}{|c|c|c|c|}
\hline $\begin{array}{l}\text { Lp./ } \\
\text { Item } \\
\text { no. }\end{array}$ & Pytania/Questions & $\begin{array}{c}\text { Odpowiedzi/ } \\
\text { Answers }\end{array}$ & $\begin{array}{l}\text { Liczba odpo- } \\
\text { wiedzi/ } \\
\text { Number of } \\
\text { answers }\end{array}$ \\
\hline & \multirow{2}{*}{$\begin{array}{l}\text { Czy potrafi Pani przeprowadzić sa- } \\
\text { mobadanie piersi?/Can you perform } \\
\text { a breast self-examination? }\end{array}$} & $\begin{array}{c}\text { Tak, potrafię/ } \\
\text { Yes, I can }\end{array}$ & 77 \\
\hline & & $\begin{array}{l}\text { Nie potrafię/ } \\
\text { No, I cannot }\end{array}$ & 23 \\
\hline
\end{tabular}




\begin{tabular}{|c|c|c|c|}
\hline \multirow{4}{*}{2.} & \multirow{4}{*}{$\begin{array}{l}\text { Jakimi technikami przeprowadza } \\
\text { Pani samobadanie piersi?/Which } \\
\text { techniques do you use when per- } \\
\text { forming a breast self-examination? }\end{array}$} & $\begin{array}{l}\text { Badanie dotykiem } \\
\text { piersi i węzłów } \\
\text { chłonnych pacho- } \\
\text { wych/Palpation } \\
\text { of the breast and } \\
\text { axillary lymph } \\
\text { nodes }\end{array}$ & 4 \\
\hline & & $\begin{array}{l}\text { Oglądanie, badanie } \\
\text { dotykiem piersi } \\
\text { i węzłów chłon- } \\
\text { nych pachowych/ } \\
\text { Observation and } \\
\text { palpation of the } \\
\text { breast and axillary } \\
\text { lymph nodes }\end{array}$ & 59 \\
\hline & & $\begin{array}{l}\text { Oglądanie i ba- } \\
\text { danie dotykiem } \\
\text { samych piersi/ } \\
\text { Observation and } \\
\text { palpation of the } \\
\text { breast alone }\end{array}$ & 14 \\
\hline & & $\begin{array}{l}\text { Nie wiem, nie } \\
\text { znam/l do not know } \\
\text { any techniques }\end{array}$ & 23 \\
\hline \multirow{5}{*}{3.} & \multirow{5}{*}{$\begin{array}{l}\text { Jak często wykonuje Pani samo- } \\
\text { badanie piersi?/How often do you } \\
\text { perform a breast self-examination? }\end{array}$} & $\begin{array}{l}\text { Raz w tygodniu/ } \\
\text { Once a week }\end{array}$ & 4 \\
\hline & & $\begin{array}{l}\text { Raz w miesiącu/ } \\
\text { Once a month }\end{array}$ & 14 \\
\hline & & $\begin{array}{l}\text { Raz na pół roku/ } \\
\text { Once during each } \\
\text { half year }\end{array}$ & 17 \\
\hline & & Rzadziej/Less often & 28 \\
\hline & & $\begin{array}{l}\text { Nie wykonuję go } \\
\text { w ogóle/l do not } \\
\text { perform it at all }\end{array}$ & 37 \\
\hline 4. & $\begin{array}{l}\text { Czy uważa Pani, że systematyczne } \\
\text { badanie piersi może przyczynić się } \\
\text { do zmniejszenia zachorowania na } \\
\text { raka piersi?/Do you believe that a } \\
\text { systematic breast examination may } \\
\text { decrease the risk of breast cancer? }\end{array}$ & Tak/Yes & 45 \\
\hline & \multirow{6}{*}{$\begin{array}{c}\text { Od kiedy według Pani należy zacząć } \\
\text { wykonywanie samobadania piersi } \\
\text { (wiek)?/In your opinion, when should } \\
\text { a woman start performing a breast } \\
\text { self-examination (age)? }\end{array}$} & $\begin{array}{c}\text { Od momentu } \\
\text { pierwszej mie- } \\
\text { siączki/Since your } \\
\text { menarche }\end{array}$ & 49 \\
\hline & & $\begin{array}{c}\text { Od 20. r.ż./ } \\
\text { ć When you are } 20\end{array}$ & 12 \\
\hline & & $\begin{array}{c}\text { Od 30. r.ż./ } \\
\text { When you are } 30\end{array}$ & 9 \\
\hline & & $\begin{array}{c}\text { Od 40. r.ż./ } \\
\text { When you are } 40 \\
\text { Od 50. r.ż./po }\end{array}$ & 18 \\
\hline & & $\begin{array}{c}\text { klimakterium/When } \\
\text { you are 50/after } \\
\text { menopause }\end{array}$ & 11 \\
\hline & & Nie wiem// do not & 1 \\
\hline \multirow{4}{*}{6.} & \multirow{4}{*}{$\begin{array}{l}\text { Kiedy według Pani powinno prze- } \\
\text { prowadzać się samobadanie piersi } \\
\text { (dzień cyklu miesiączkowego)?/In } \\
\text { your opinion, when a breast self- } \\
\text {-examination should be performed } \\
\text { (day of the menstrual cycle)? }\end{array}$} & $\begin{array}{l}\text { Tydzień po men- } \\
\text { struacji/A week }\end{array}$ & 51 \\
\hline & & $\begin{array}{l}\text { Tydzień przed } \\
\text { menstruacją/ } \\
\text { A week before } \\
\text { menstruation }\end{array}$ & 16 \\
\hline & & $\begin{array}{c}\text { Niezależnie od } \\
\text { cyklu/Regardless of } \\
\text { the cycle }\end{array}$ & 15 \\
\hline & & Nie wiem// do not & 18 \\
\hline
\end{tabular}

\begin{tabular}{|c|c|c|c|}
\hline \multirow{4}{*}{7.} & \multirow{4}{*}{$\begin{array}{l}\text { Gdy zauważa Pani zmiany w okoli- } \\
\text { cach piersi podczas samobadania, } \\
\text { co Pani robi?/What do you do when } \\
\text { you notice a change in the breast } \\
\text { during your self-examination? }\end{array}$} & $\begin{array}{l}\text { Czekam, aby zo- } \\
\text { baczyć, co będzie } \\
\text { dalej/l wait to see } \\
\text { what happens next }\end{array}$ & 21 \\
\hline & & $\begin{array}{c}\text { Udaję się do } \\
\text { lekarza/l go to the } \\
\text { doctor }\end{array}$ & 70 \\
\hline & & $\begin{array}{c}\text { Nic nie robię/l do } \\
\text { nothing }\end{array}$ & 5 \\
\hline & & $\begin{array}{l}\text { Szukam odpowie- } \\
\text { dzi w literaturze/ } \\
\text { I look for the answer } \\
\text { in the literature }\end{array}$ & 4 \\
\hline \multirow[t]{2}{*}{8.} & $\begin{array}{c}\text { Czy uważa Pani, że samobadanie } \\
\text { powinno się przeprowadzać syste- } \\
\text { matycznie?/Do you think that } \\
\text { a breast self-examination should be }\end{array}$ & Tak/Yes & 88 \\
\hline & performed systematically? & $\mathrm{Nie} / \mathrm{No}$ & 12 \\
\hline
\end{tabular}

Źródło: opracowanie własne

Source: author's own analysis

Zdecydowana większość respondentek wie, że mammografia jest najbardziej efektywną metodą wykrycia raka piersi, zaś zaledwie połowa ankietowanych miała kiedykolwiek robione badanie mammograficzne lub USG piersi (Tabela 5).

Tabela 5. Wiedza pacjentek oddziału chirurgicznego Wojewódzkiego Szpitala Specjalistycznego w Radomiu dotycząca badania mammograficznego/USG piersi

Table 5. Knowledge of female patients hospitalized in the surgical department of the Regional Specialist Hospital in Radom about the mammographic screening/breast ultrasound

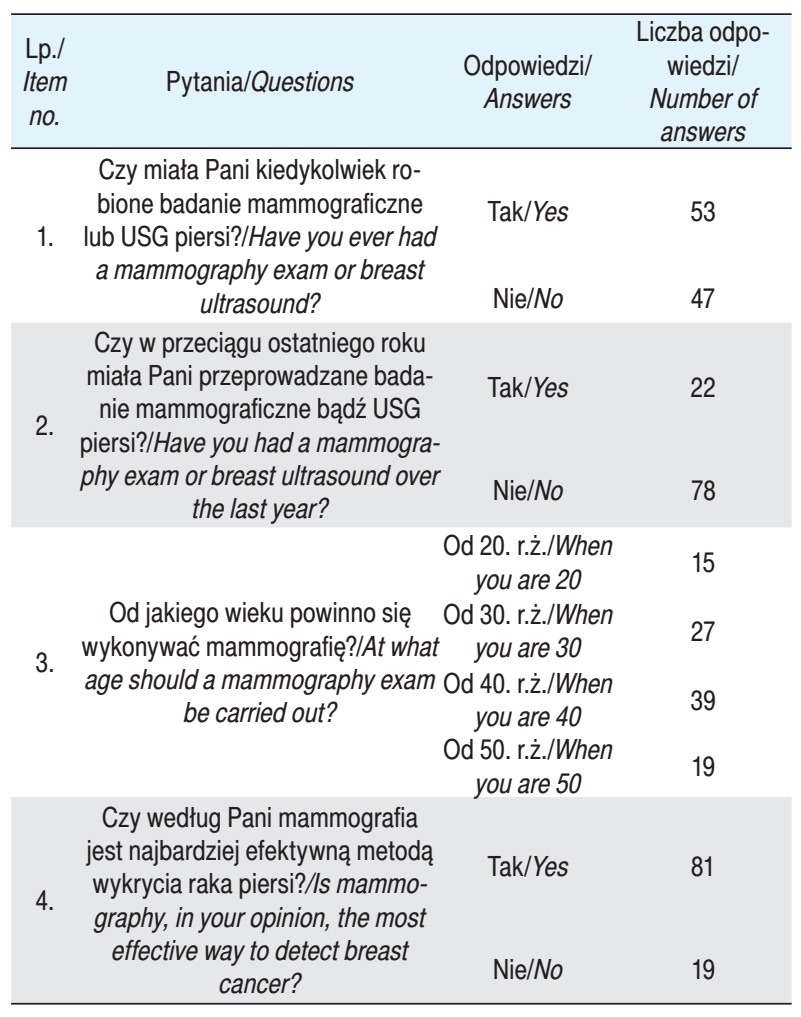

Źródło: opracowanie własne

Source: author's own analysis 
Spośród możliwych odpowiedzi na pytanie dotyczące największych kłopotów w samoopiece po mastektomii ponad połowa respondentek oznaczyła, że dla nich najbardziej problematyczne są kontakty z otoczeniem, a dopiero potem pielęgnacja rany bądź ćwiczenia. Ponadto według badanych pacjentek najodpowiedniejszym źródłem do zapoznania z takimi zasadami jest personel medyczny: lekarze, pielęgniarki. Zaledwie 8 kobiet wiedziało, że samoopiekę po zabiegu mastektomii należy rozpocząć bezpośrednio po zabiegu. Szczegółowe dane przedstawia tabela 6.

Tabela 6. Poziom wiedzy pacjentek oddziału chirurgicznego Wojewódzkiego Szpitala Specjalistycznego w Radomiu na temat samoopieki po zabiegu mastektomii

Table 6. Level of knowledge of female patients hospitalized in the surgical department of the Regional Specialist Hospital in Radom about post mastectomy self-care care

\begin{tabular}{|c|c|c|c|}
\hline $\begin{array}{l}\text { Lp./ } \\
\text { Item } \\
\text { no. }\end{array}$ & Pytania/Questions & Odpowiedzi/Answers & $\begin{array}{l}\text { Liczba odpo- } \\
\text { wiedzi/ } \\
\text { Number of } \\
\text { answers }\end{array}$ \\
\hline \multirow{7}{*}{1.} & \multirow{7}{*}{$\begin{array}{l}\text { Jakie czynności w samoopie- } \\
\text { ce według Pani stwarzają } \\
\text { największe kłopoty? (można } \\
\text { zaznaczyć kilka odpowiedzi)/ } \\
\text { In your opinion, which activi- } \\
\text { ties are the most problematic } \\
\text { in self-care? (more than one } \\
\text { answer can be chosen) }\end{array}$} & $\begin{array}{c}\text { Mycie się/ } \\
\text { Washing yourself }\end{array}$ & 34 \\
\hline & & $\begin{array}{l}\text { Ubieranie się/ } \\
\text { Getting dressed }\end{array}$ & 37 \\
\hline & & $\begin{array}{l}\text { Pielęgnacja rany po- } \\
\text { operacyjnej/ } \\
\text { Surgical wound care }\end{array}$ & 45 \\
\hline & & $\begin{array}{c}\text { Spożywanie posiłków/ } \\
\text { Eating }\end{array}$ & 28 \\
\hline & & Ćwiczenia/Exercising & 44 \\
\hline & & $\begin{array}{l}\text { Masaż limfatyczny/ } \\
\text { Lymphatic massage }\end{array}$ & 41 \\
\hline & & $\begin{array}{l}\text { Kontakty z ludźmi/ } \\
\text { Social relations }\end{array}$ & 52 \\
\hline \multirow{7}{*}{2.} & \multirow{7}{*}{$\begin{array}{l}\text { Kto Pani zdaniem powinien } \\
\text { zapoznać z zasadami samo- } \\
\text { opieki na oddziale i/lub skąd } \\
\text { takie informacje czerpać? } \\
\text { (można zaznaczyć kilka } \\
\text { odpowiedzi)/ } \\
\text { In your opinion, who should } \\
\text { inform a patient on the } \\
\text { principles of self-care at the } \\
\text { department and/or where } \\
\text { should a patient look for such } \\
\text { information? (more than one } \\
\text { answer can be chosen) }\end{array}$} & Lekarz/Physician & 81 \\
\hline & & Pielęgniarka/Nurse & 62 \\
\hline & & $\begin{array}{c}\text { Współpacjentka } \\
\text { wolontariuszka z klubu } \\
\text { wsparcia „Amazonka”/ } \\
\text { Fellow patient } \\
\text { volunteer from the Ama- } \\
\text { zon Support Group }\end{array}$ & 44 \\
\hline & & $\begin{array}{l}\text { Ktoś z rodziny/znajomi/ } \\
\text { Family member/friends }\end{array}$ & 39 \\
\hline & & $\begin{array}{l}\text { Z książek, ulotek/ } \\
\text { Books, leaflets }\end{array}$ & 52 \\
\hline & & Z Internetu/Internet & 37 \\
\hline & & Inne/Other & - \\
\hline \multirow{4}{*}{3.} & \multirow{4}{*}{$\begin{array}{l}\text { Kiedy według Pani należy } \\
\text { rozpocząć samoopiekę/When } \\
\text { should self-care be started? }\end{array}$} & $\begin{array}{c}\text { Bezpośrednio po } \\
\text { zabiegu/Right after the } \\
\text { surgery }\end{array}$ & 8 \\
\hline & & $\begin{array}{l}\text { Po wyjściu ze szpitala/ } \\
\text { After leaving hospital }\end{array}$ & 40 \\
\hline & & $\begin{array}{l}2 \text { dni po zabiegu/Two } \\
\text { days after the surgery }\end{array}$ & 21 \\
\hline & & $\begin{array}{c}\text { Po zdjęciu szwów/After } \\
\text { removal of stitches }\end{array}$ & 31 \\
\hline
\end{tabular}

Źródło: opracowanie własne

Source: author's own analysis
Większość kobiet biorących udział w badaniu pozyskuje informacje na temat profilaktyki raka piersi z telewizji, radia, gazet. Tylko 25 respondentek czerpie wiedzę na ten temat również z innych źródeł, m.in.: broszur, plakatów, literatury naukowej. Ponadto według ankietowanych największą przeszkodą w działaniach profilaktycznych jest brak środków materialnych oraz brak wiedzy (Tabela 7).

Tabela 7. Wiedza respondentek z oddziału chirurgicznego Wojewódzkiego Szpitala Specjalistycznego w Radomiu na temat profilaktyki raka piersi

Table 7. Knowledge of female patients hospitalized in the surgical department of the Regional Specialist Hospital in Radom about breast cancer prophylaxis

\begin{tabular}{|c|c|c|c|}
\hline $\begin{array}{l}\text { Lp./ } \\
\text { Item } \\
\text { no. }\end{array}$ & Pytania/Questions & Odpowiedzi/Answers & $\begin{array}{l}\text { Liczba odpo- } \\
\text { wiedzi/ } \\
\text { Number of } \\
\text { answers }\end{array}$ \\
\hline \multirow[b]{4}{*}{1.} & Skąd czerpie Pani wiedzę na temat & $\begin{array}{c}\text { Z TV/radia/gazet/ } \\
\text { Television/radio/press }\end{array}$ & 73 \\
\hline & profilaktyki raka piersi? (można & Z Internetu/Internet & 52 \\
\hline & zaznaczyć kilka odpowiedzi)/What & Od lekarza/Physician & 55 \\
\hline & $\begin{array}{l}\text { is your source of knowledge } \\
\text { of breast cancer prophylaxis? } \\
\text { (more than one answer can be }\end{array}$ & $\begin{array}{l}\text { Od znajomych/ } \\
\text { Friends }\end{array}$ & 43 \\
\hline
\end{tabular}
chosen)

Inne źródło/Other sources

„Amazonki"/The

Amazons Movement

81

Czy słyszała lub zna Pani któ- $\quad \begin{array}{r}\text { Polski Komitet Zwal- } \\ \text { czania Raka/The }\end{array}$ rąkolwiek z obok wymienionych Polish Committee for instytucji i organizacji zajmują- Cancer Control cych się profilaktyką raka piersi? Polska Unia Onkolo(można zaznaczyć kilka odpow- gii/The Polish Union

2. iedzi)/Have you ever heard of or gil/The Polish Un do you know any of the following Kampania AVON institutions and organizations Różowa Wstążka/ concerned with breast cancer $\quad$ AVON Pink Ribbon prophylaxis? (more than one Campaign answer can be chosen) Inne/Other
Intomaign Nie znam/l do not know any of them

Co według Pani może stanowić Brak zaufania do przeszkodę w działaniach lekarzy/A lack of trust profilaktycznych mogących in doctors

zmniejszyć ryzyko zachorowania Brak środków matena raka piersi? rialnych/A shortage of

3. (można zaznaczyć kilka odpowiedzi)/ material resources In you opinion, what may ob- Brak wiedzy/Lack of struct the prophylactic activities knowledge aimed at reducing the risk of Brak czasu/Lack of breast cancer? (more than one time answer can be chosen) 


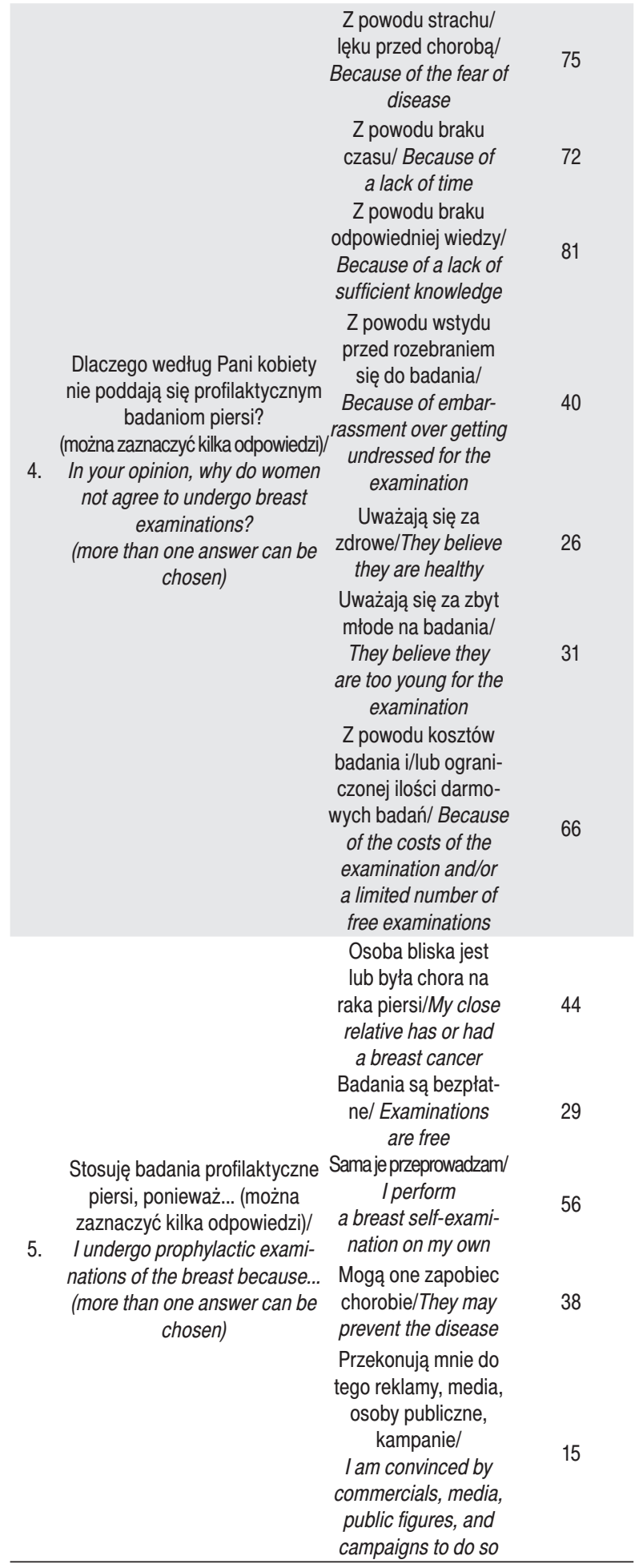

Źródło: opracowanie własne

Source: author's own analysis

\section{Dyskusja}

Rak sutka jest w ostatnich latach szeroko poruszanym problemem w środkach masowego przekazu. Chorobie tej nie można zapobiec, a sukces w leczeniu zależy od stopnia zaawansowania, czyli od najwcześniejszego wykrycia zmian w piersiach. Dlatego bardzo ważne jest uświadomienie sobie, jaki jest poziom wiedzy kobiet na temat profilaktyki raka piersi, w tym zasad samoopieki po zabiegu oraz kształtowania właściwych postaw zdrowotnych w codziennym życiu. W badaniach własnych zebrano dane dotyczące wiedzy pacjentek oddziału chirurgicznego Wojewódzkiego Szpitala Specjalistycznego w Radomiu z zakresu zasad samoopieki po zabiegu mastektomii.

W dostępnej literaturze nie ma publikacji badań dotyczących pacjentek oddziału chirurgicznego. Literatura dostarcza wiele informacji o nowotworze złośliwym piersi i zasad samoopieki po zabiegu mastektomii. Tak więc dyskusja ta będzie opierała się na wynikach badań zamieszczonych w literaturze z zakresu profilaktyki raka piersi [4-7]. Badania Zych i wsp. zostały przeprowadzone na przełomie 2005 i 2006 r. w grupie 112 kobiet zamieszkujących Rzeszów i okolice. Kobiety te przed badaniem odbyły zajęcia edukacyjne w zakresie profilaktyki raka piersi. Poziom wiedzy na temat profilaktyki raka piersi osoba badająca określiła jako niepełny, a w stosunku do znajomości czynników ryzyka raka sutka - jako średni. Respondentki za najczęstszą przyczynę nowotworu uznały uwarunkowania genetyczne (92\%), okres przekwitania (72,3\%), stosowanie antykoncepcji $(71,4 \%)$, palenie papierosów $(68,7 \%)$ - ten ostatni czynnik w świetle aktualnych badań jest wykluczony jako przyczyna powstawania raka sutka [8]. W badaniu własnym wyniki na temat znajomości czynników ryzyka raka sutka były zdecydowanie gorsze. Identycznie jak w badaniu Zych i wsp. najbardziej charakterystycznym czynnikiem ryzyka zachorowania na raka piersi jest czynnik genetyczny. Jedynie dla ok. 20\% respondentek okres przekwitania i stosowana antykoncepcja mogą być czynnikami zachorowania na raka sutka. Wpływ na uzyskanie gorszych wyników może mieć fakt, iż na badanej grupie pacjentek oddziału chirurgicznego nie przeprowadzono wcześniej edukacji w zakresie profilaktyki raka piersi. Uzyskane wyniki są porównywalne z wynikami Trusz i wsp., których badanie objęło 200 studentek Wydziału Nauki o Zdrowiu Warszawskiego Uniwersytetu Medycznego. Czynnikiem ryzyka raka piersi według respondentek jest dziedziczność $(89,5 \%$ badanych kobiet), 32,5\% uważa, że opalanie topless może być czynnikiem predysponującym do wystąpienia tej choroby, dla 18,5\% badanych - wczesne dojrzewanie, a dla 25,5\% respondentek - późna menopauza [9]. Ministerstwo Zdrowia, Narodowy Fundusz Zdrowia, Polski Komitet Zwalczania Raka oraz wiele innych stowarzyszeń na rzecz walki z rakiem piersi prowadzą szereg ogólnopolskich akcji, które są nagłaśniane w radiu, telewizji oraz prasie kobiecej. Dla 61\% respondentek, które wzięły udział w badaniach Banach i wsp. przeprowadzonych w Zakładzie Profilaktyki i Promo- 
cji Zdrowia Centrum Onkologii w Bydgoszczy na 499 kobietach poddanych wcześniej edukacji zdrowotnej, podstawowym źródłem wiedzy na temat raka piersi są prasa i ulotki, a dla 54\% - telewizja i radio. Większość (70\%) studentek Wydziału Nauki o Zdrowiu Warszawskiego Uniwersytetu Medycznego badanych przez Trusz i wsp. poprawnie definiuje „Różową Wstążkę" jako akcję związaną z szerzeniem wiedzy na temat profilaktyki raka piersi [10]. Wyniki badań własnych z powyższymi wynikami Trusz i wsp. były porównywalne. Akcja firmy AVON „Różowa Wstążka” znana była dla $65 \%$ pacjentek oddziału chirurgicznego. Jednakże dla respondentek najbardziej charakterystyczną instytucją związaną z profilaktyką raka piersi było stowarzyszenie „Amazonki”. Natomiast w stosunku do badań Banach i wsp. wyniki własne były lepsze. Ponad trzy czwarte ankietowanych kobiet czerpie informacje na temat profilaktyki raka piersi z telewizji, radia i gazet. Celem badania Nity i wsp. z 2005 r., przeprowadzonego wśród losowo wybranych kobiet odwiedzających lub matek dzieci hospitalizowanych w Klinice Ortopedii i Traumatologii Instytutu Centrum Zdrowia Matki Polki w Łodzi, była analiza wiedzy i zachowań kobiet z województwa łódzkiego w zakresie profilaktyki raka piersi. Jedynie $17,4 \%$ respondentek przeprowadza samobadanie regularnie, $32,1 \%$ kobiet bada się nieregularnie, od czasu do czasu, a $12 \%$ nie wie nawet, jak je wykonać. Jeśli chodzi o badania profilaktyczne, aż 70,4\% ankietowanych kobiet nie miało nigdy wykonywanego badania mammograficznego [11]. W badaniach własnych uzyskano podobne wyniki. Również mniej więcej co trzecia ankietowana kobieta przeprowadza samobadanie piersi regularnie. W badaniach własnych stwierdzono, że prawie dwa razy więcej respondentek niż w badaniach Nity i wsp. nie potrafi wykonać samobadania piersi. Powodem gorszych wyników może być fakt, iż w badaniach własnych brało udział więcej starszych kobiet i nie było limitu wieku jak w badaniach Nity (do 60. roku życia). Spośród respondentek $80 \%$ kobiet po 60. roku życia nie ma takich umiejętności. W badaniu Banach i wsp. w grupie badanych obejmującej 499 kobiet aż 305 osób uważa, że najrzetelniejszym źródłem wiedzy na temat zasad samoopieki po zabiegu mastektomii są książki, ulotki i czasopisma. Jedynie 172 osoby (34,5\% ankietowanych) wymieniły podmioty służby zdrowia (lekarzy, pielęgniarki) jako autorytet w zapoznaniu z zasadami samoopieki po zabiegu mastektomii. W badaniach własnych uzyskano lepsze wyniki. Dla większości respondentek najodpowiedniejszym podmiotem w udzieleniu takich informacji jest lekarz, następnie pielęgniarka. Dopiero na czwartym miejscu znajduje się specjalistyczna literatura. Wyniki, jakie uzyskano w pracy, świadczą o ogromnym zapotrzebowaniu na wprowadzenie rozwi- niętej, skoordynowanej, systematycznej i dostosowanej do indywidualnych potrzeb kobiet edukacji zdrowotnej na temat profilaktyki raka piersi, a w przypadku zachorowania i koniecznego zabiegu mastektomii - propagowania zasad samoopieki. Działania takie mogłyby korzystnie wpłynąć na poziom wiedzy reprezentowanej przez kobiety, wykształciłyby prawidłowe postawy zachowań zarówno na etapie początkowym (w którym tak ważne jest jak najszybsze wykrycie zmian w piersiach), jak i w okresie leczenia i rehabilitacji. Przyczynić mogłoby się to również do polepszenia stanu fizycznego, psychicznego oraz poczucia kontroli nad własnym organizmem. Trzeba również uświadamiać kobiety o możliwości wystąpienia powikłań po zabiegu operacyjnym oraz nauczyć postępowania w sytuacji zaobserwowania objawów mogących stanowić zagrożenie dla zdrowia bądź życia. Osobami, które w takiej sytuacji mogą wykazać się szerokimi kompetencjami i zdolnościami oraz cieszącymi się dużym autorytetem, są lekarze i pielęgniarki.

\section{Wnioski}

1. Uzyskane wyniki badań świadczą o niedostatecznej wiedzy pacjentek oddziału chirurgicznego na temat zasad samoopieki po zabiegu mastektomii.

2. Poziom wiedzy respondentek na temat profilaktyki raka piersi w znaczny sposób wpływa na podejmowane przez nie działania prewencyjne.

3. Wyniki badań własnych potwierdzają tezę, że brak ogólnodostępnych publikacji i szeroko zakrojonej edukacji na temat profilaktyki raka piersi, a zwłaszcza samoopieki po zabiegu mastektomii ma wpływ na poziom wiedzy kobiet.

4. Według badanej grupy kobiet lekarze i pielęgniarki są najodpowiedniejszymi podmiotami do zapoznawania z zasadami samoopieki po zabiegu mastektomii, ale są oni za mało zaangażowani w szerzenie wiedzy na ten temat.

5. Badania mają charakter pilotażowy i powinny byćkontynuowane w liczebniejszej grupie i przeprowadzone szeroko wśród kobiet i mężczyzn - potencjalnych członków rodziny, przyjaciół z uwagi na wsparcie, którego może potrzebować osoba, która zachoruje na raka piersi.

\section{Piśmiennictwo}

1. Uchman P, Stanek J, Sajdak S, Bręborowicz G. Zmiany nowotworowe narządów płciowych i sutka. W: Opala T (red.). Ginekologia. Podręcznik dla położnych, pielęgniarek i fizjoterapeutów. Warszawa: PZWL; 2006. 239.

2. Goworek P, Durka M, Borowiak E, Cieślak H. Wiedza na temat samobadania piersi wśród kobiet zamieszkujących w Polsce i w Nowej Zelandii. Probl Piel. 2008; 16 $(1,2): 146$. 
3. Narodowy program zwalczania chorób nowotworowych. Warszawa: Ministerstwo Zdrowia, Departament Polityki Zdrowotnej; 2005.1.

4. Stodólno U. Rehabilitacja po mastektomii. Mag Piel Położ. 2002; 7-8: 30.

5. Cieślak H, Wysokiński M, Fidecki W. Wybrane determinanty pielęgniarstwa. Część IV. Warszawa: Oficyna Wydawnicza Warszawskiego Uniwersytetu Medycznego; 2010. 212-214.

6. Lissowska J. Rak piersi: etiologia i prewencja pierwotna. Wokół kontrowersyjnych hipotez. Rozprawa habilitacyjna. Warszawa: Centrum Onkologii - Instytut im. Marii Skłodowskiej-Curie; 2008.

7. Stoppard M. W trosce o twoje piersi. Warszawa: Kaliope Oficyna Wydawnicza; 2007.

8. Zych B, Kusek E, Pasternak K, Sztance M. Znajomość profilaktyki raka sutka wśród kobiet. Piel XXI w. 2006; 3 (16): 115-118.

9. Trusz J, Michota-Katulska E, Paszek T, Sienkiewicz Z. Wiedza młodzieży akademickiej z zakresu profilaktyki raka piersi. W: Cieślak $\mathrm{H}$ (red.). Wybrane determinanty pielęgniarstwa. Warszawa; 2010. 197-215.

10. Bannach M, Grabiec M, Rybka M. Profilaktyka w walce z rakiem piersi i rakiem szyjki macicy. Piel XXI w. 2005; 3 (12): $125-130$
11. Nita R, Leśniak B, Słomska B, Dominowska J, Krasomski G. Wiedza i zachowania zdrowotne kobiet $z$ województwa łódzkiego w zakresie profilaktyki raka piersi. Piel XXI w. 2010; 1-3 (30-31): 5-8.

Artykuł przyjęty do redakcji: 08.07.2015

Artykuł przyjęty do publikacji: 11.12.2015

Źródło finansowania: Praca nie jest finansowana z żadnego źródła. Konflikt interesów: Autorzy deklarują brak konfliktu interesów.

Adres do korespondencji:

Joanna Gotlib

ul. Żwirki i Wigury 61

02-091 Warszawa

tel.: 225720 490, fax: 225720 491, tel. kom.: +48 608108028

e-mail: joanna.gotlib@wum.edu.pl

Zakład Dydaktyki i Efektów Kształcenia

Warszawski Uniwersytet Medyczny 